\title{
Islamic Banks, Deposit Insurance Reform, and Market Discipline: Evidence from a Natural Framework
}

\author{
Ahmet F. Aysan ${ }^{1} \cdot$ Mustafa Disli $^{2} \cdot$ Meryem Duygun $^{3} \cdot$ \\ Huseyin Ozturk ${ }^{1}$
}

Received: 13 January 2015 /Revised: 20 March 2016 / Accepted: 8 April 2016 /

Published online: 25 April 2016

(C) Springer Science+Business Media New York 2017

\begin{abstract}
Although it has been intensively claimed that Islamic banks are subject to more market discipline, the empirical literature is surprisingly mute on this topic. To fill this gap and to verify the conjecture that Islamic bank depositors are indeed able to monitor and discipline their banks, we use Turkey as a test setting. The theory of market discipline predicts that when excessive risk taking occurs, depositors will ask higher returns on their deposits or withdraw their funds. We look at the effect of the deposit insurance reform in which the dual deposit insurance was revised and all banks were put under the same deposit insurance company in December 2005. This gives us a natural experiment in which the effect of the reform can be compared for the treatment group (i.e., Islamic banks) and control group (i.e., conventional banks). We find that the deposit insurance reform has increased the market discipline in the Turkish Islamic banking sector. This reform may have upset the sensitivities of the religiously inspired depositors, and perhaps more importantly it might have terminated the existing mutual supervision and support among Islamic banks.
\end{abstract}

Keywords Depositor discipline · Islamic banks

Mustafa Disli

mustafa.disli@ugent.be

Ahmet F. Aysan

ahmet.aysan@tcmb.gov.tr

Meryem Duygun

meryem.duygun@nottingham.ac.uk

Huseyin Ozturk

huseyin.ozturk@tcmb.gov.tr

1 Central Bank of the Republic of Turkey, Ankara, Turkey

2 Ghent University, Tweekerkenstraat 2, 9000 Gent, Belgium

3 Nottingham University Business School, Nottingham, UK 
JEL Codes $\mathrm{G} 23 \cdot \mathrm{G} 28 \cdot \mathrm{O} 52$

\section{Introduction}

The motivation behind market discipline is to increase the role of depositors to supplement regulatory discipline. The growing complexity of banking activities and the move towards market-based banking provide an explanation for why subsequent Basel reforms have increasingly stressed the role of market discipline as a pillar for a safe and efficient financial system. Market discipline refers to a market-based incentive scheme, whereby depositors or other creditors actively reward or punish banks for their relative performance. The underlying theory of market discipline predicts that depositors will ask higher returns on their deposits and/or withdraw their funds in response to declining bank fundamentals. This mechanism of market discipline operates through both price and quantity adjustments in bank liabilities, which, in turn, would force bank management to lessen its risk taking (Flannery 1998; Park and Peristiani 1998; Martinez Peria and Schmukler 2001).

The existence of market discipline in conventional banking markets is well-documented and reflected in the literature. Much of this evidence comes from countries with mature and welldeveloped banking systems. Both price and quantity disciplining have been shown to play an important role as a complement to supervisory efforts, particularly with respect to deposits that are not fully insured. For example, using a sample of banks in thirty-two OECD countries, Nier and Baumann (2006) find that riskier banks in general hold a bigger capital buffer, which confirms the presence of market disciplining behavior in more mature institutional environments. Sironi (2003) yields a similar conclusion by analyzing the risk sensitivity of European banks' subordinated notes and debentures spreads. For a sample of both OECD and developing countries, Demirgüç-Kunt and Huizinga (2004) find that depositors impose market discipline on banks to a lesser extent when there is an explicit deposit insurance system.

The Islamic banking system distinguish itself from the conventional system because interest (riba) is prohibited in Islam; i.e., banks are not permitted to charge predetermined interest rates on loans or savings. In accordance with the Shariah, the Islamic legal rules, the Islamic banking model is based on the profit-and-loss sharing mechanism (PLS), which is typically practiced through Mudarabah (profit-sharing) and Musharaka (joint venture) contracts. Under the PLS arrangement, bank assets and liabilities are balanced in such a way that borrowers share profits and losses with banks, which then share these profits and losses with depositors. Given the emphasis on equity financing, advocates of Islamic banking have argued that the deleveraged nature of Islamic banks contribute to the stability of the financial system (Khan and Mirakhor 1989; Ebrahim and Safadi 1995; Iqbal 1997). Čihák and Hesse (2010), Hasan and Dridi (2011) and Beck et al. (2013), among others, provide empirical evidence that Islamic banks better withstand negative shocks than conventional banks. Instead of debt, the Islamic banking model introduces asset-backed financing instruments, where the investor's return is linked to the profit and loss of a pool of heterogeneous assets (Askari 2012). In addition, Chapra (1992) and Mills and Presley (1999) argue that the risk-sharing feature of the PLS paradigm allows Islamic banks to lend on longer-term basis to projects with better risk-return profiles and, thus, promote economic growth.

More importantly for the purpose of our study, given the equity-like nature of savings and investment deposits, it has been strongly claimed that Islamic banks are more subject to market discipline (e.g., Errico and Farahbaksh 1998; El-Hawary et al. 2004; Beck et al. 
2013). In other words, as 'quasi-shareholders', Islamic bank depositors would have greater incentives to exercise control over management to prevent excessive risk taking behavior. By assessing the presence of market discipline, this article contributes to the small but growing Islamic finance literature in several ways. To the best of our knowledge there has been no empirical study examining the existence of market discipline in a dual banking system, where Islamic and conventional banks operate side by side. Moreover, the existing literature does not provide us clear insights into how the disciplining mechanism operates in the Islamic setting. We attempt to fill this gap by examining depositors' disciplining behavior in the Turkish banking market. While in a few countries, such as Iran and Sudan, the entire banking industry operates according to Islamic rules, in many other countries, such as Bangladesh, Egypt, Malaysia and Turkey, Islamic financial institutions are running side-by-side with conventional banks. The Turkish case provides an interesting opportunity to test the dynamics of depositors' behavior. Turkey was the first country in the world that had adopted a dual deposit insurance framework in 2001, in which the Islamic deposit insurance scheme operated alongside its conventional counterpart. Unlike the conventional scheme, which was administered by the government, the Islamic scheme was organized and managed by Islamic banks. However, on December 2005, the dual deposit insurance framework was revised and the Islamic scheme was absorbed by the conventional scheme. We exploit this natural experiment to study the impact of the unified deposit insurance system on market discipline using a difference-indifferences approach. By analyzing the Russian banking market, Karas et al. (2013) adopted a similar empirical strategy in order to identify the differential effect of deposit insurance on the behaviors of insured households and uninsured firms. We instead compare the presence of market discipline among Islamic banks with a control group of conventional banks that are not affected by the deposit insurance reform.

Our findings suggest that Islamic bank depositors indeed behave differently than their conventional peers. In the pre-deposit insurance reform period, we observe that depositors of conventional banks were sensitive to bank risk, whereas the vigilance of Islamic depositors was not present. In the post-reform period, however, we find that Islamic bank depositors increased their sensitivity to bank-specific risks. We interpret these findings as evidence that the reform may have upset the sensitivities of religiously inspired depositors. Furthermore, the reform may have terminated the mutual supervision and support among Islamic banks. Robustness checks, in the form of incorporating the 2001 financial crisis in our analyses, confirm that the presence of the Islamic deposit insurance scheme had a numbing effect on market discipline.

We organize this article as follows. In Section 2, we describe the disciplining process in the Islamic banking sector. Section 3 presents a concise history of the dual-banking industry in Turkey. In Section 4, we describe the sample of banks, and identify the impact of the deposit insurance reform on market discipline. Section 5 presents the results of the difference-indifference estimation strategy. Section 6 extends our sample period, look at the influence of the 2001 financial crisis on market discipline, and also functions as a robustness analysis. In Section 7, we summarize our main findings and provide a discussion of the results found.

\section{Market discipline in Islamic banks}

Although the Islamic finance literature has highlighted the importance of market discipline, still very little is known about the mechanism through which the disciplining occurs in a profit 
and loss sharing framework (Aysan et al. 2015). Particular focus in this context is on the Mudaraba contract, which involves a partnership between the bank as one of the several investors, with profits and losses being shared in mutually agreed proportions. This mode of financing is manifested on the banks' liabilities side, with investment accounts or deposits that do not yield preset interest rates but rather confer a proportion of profits. An Islamic deposit contract, in fact, contains neither debt nor equity-based compensations - and this, in turn, may create additional agency conflicts. Agency problems do not only stem from the separation of ownership and control for shareholders (Berle and Means 1932; Jensen and Meckling 1976; Fama and Jensen 1983), but are also sourced from the separation of cash flow and control rights for depositors (Safieddine 2009). Although in such an arrangement depositors turn from bank creditors to residual claimants on banks' cash flows, they are not granted the control rights that shareholders enjoy and their cash flow rights are separated from the rights to control the investments.

Recent corporate finance theories posit that corporate governance is increasingly based on exit strategies rather than on voice. These theories conjecture that, in the absence of intervention power, dispersed blockholders can govern firms (Edmans 2009; Admati and Pfleiderer 2009; and Edmans and Manso 2011). While such a dispersed structure appears to be a barrier for direct intervention, it strengthens the role of a second governance mechanism: disciplining through trading. This behavior involves an exit strategy upon negative information, thus leading to a stock price that closely reflects the firm's fundamental value. The drop in the stock price involves the punishment of equity-linked managers, while ex-ante the mere threat of exit raises efficiency as it induces managers to undertake value-enhancing activities.

The voice through exit mechanism is especially applicable to the Islamic model of banking. According to this model, deposits are considered as shares (i.e., equity participation) and are thus entitled to dividends if the investment operates at a profit (Bashir et al. 1993). Although demand deposits are not tradable, they are highly liquid by their very nature. Deposits typically contain a withdrawal option embedded with each account, which licenses the depositor to sell the deposit to the bank at will. Calomiris and Kahn (1991) explain that, in a risk-sharing framework, liquid deposits substantially help to align the bank's portfolio choice with depositors' preferences. If the bank fundamentals turn out to be weak, depositors still could exercise power over bank management due to their ability to withdraw their deposits when information indicates poor firm prospects. Such an exit by depositors can be an effective governance mechanism, even when they have no direct intervention power in the operation of the banks.

Although a profit-and-loss sharing framework may contribute to market discipline, the influence of religious commitment on depositors' sensitivity to bank financial conditions is not unequivocal. On the one hand, the findings of prior research generally suggest that religious individuals show more risk-averse characteristics than non-religious individuals. For example, Miller and Hoffmann (1995) report a negative association at the individual level between religiosity and attitudes towards risk. Similarly, Hilary and Hui (2009) show that corporate policies of US firms located in more religious regions display lower degrees of risk exposure. Extending this intuition to the market discipline mechanism, we expect that Islamic bank depositors will be more vigilant and responsive to bankspecific risks. On the other hand, Abedifar et al. (2013) point that Islamic depositors may have a strong sense of loyalty toward their banks, thus numbing the sensitivity to bank riskiness. This loyalty argument is likely to be more relevant in dual-banking systems where Islamic banks are minor players in the market. In other words, in such banking systems, religious reasons may play a strong role in the decision to bypass conventional 
banks and to deposit funds to Islamic banks. This conjecture has recently been evidenced by Baele et al. (2014) with respect to the loan market in Pakistan. Their finding of much lower default rates on Islamic loans than those on conventional loans suggests that the signing of an Islamic loan contract activates religious moral norms.

In part because of the only recent institution of deposit insurance schemes for Islamic banks, the literature is also silent regarding the impact of deposit coverage on market discipline. Since the funds of the deposit insurance scheme may be invested in interest-bearing assets, concerns are raised about its compliance with Shariah principles (Solé 2007). In addition, because of the existence of different modes of Islamic deposit insurance, clear-cut interpretations about the impact of deposit insurance on market discipline are elusive. There are broadly two forms of Islamic deposit insurance, protection of Islamic deposits through the conventional insurance system or through the establishment of a separate Islamic deposit insurance scheme. As for conventional banks, we expect that deposit insurance will affect the incentives of Islamic depositors to exert market discipline. ${ }^{1}$ However, both insurance forms can have different implications on the disciplining intensity. In order to mitigate the lack of clarity in the insurability of profit-sharing deposit accounts, a dual-deposit insurance framework may provide a clear signal to Islamic depositors that the Islamic scheme is Shariah-compliant. Hence, the dualscheme may create confidence about Shariah-conformity of the reimbursed funds in case of bankruptcy. Conversely, the conventional insurance scheme, that covers both Islamic and conventional deposits, may face difficulties in convincing depositors about the reliability of reimbursed funds when a bank failure occurs. Depending on the intensity of religious devotion, even in the presence of blanket guarantee, depositors still might discipline their Islamic bank under a conventional insurance scheme.

\section{Turkish dual-banking system and deposit insurance reform}

Parallel to the growth in the Islamic finance industry worldwide, Islamic banks in Turkey have also been expanding and attracting new customers. Interest-free banking has long been present in Turkey and was first made legal in 1983, as part of a plan to draw deposits from religious citizens and from the Gulf states, under the government of Turgut Özal, a former prime minister and president of the Turkish Republic. Islamic finance debuted in 1985 with the Bahrain-based AlBaraka Turk and the Saudi-based Faisal Finans. The Kuwaiti-based Kuveyt Turk began its operations in 1989. Afterwards, the special finance houses also began lending with domestic capital,

\footnotetext{
${ }^{1}$ The impact of deposit insurance on the disciplining behavior of conventional depositors is well-documented. The existence of deposit insurance entails a trade-off between bank stability and moral hazard. Using crosscountry data, Demirgüç-Kunt and Detragiache (2002) provide evidence that explicit deposit insurance significantly increases the incidences of financial crisis. Demirgüç-Kunt and Huizinga's (2004) finding show that this increase in financial fragility mainly stems from reduced depositors' incentives to monitor and discipline banks. In developing countries, however, it is frequently observed that deposit insurance schemes are not fully credible. Martinez Peria and Schmukler (2001) proved that depositors are also concerned about the solvency of the insurance fund by showing that small-insured depositors still react to bank risk. Prean and Stix (2011) and Disli et al. (2013) show that the credibility of generous deposit insurance schemes are especially affected in turbulent economic environments.
} 
including Anadolu Finans in 1991, Ihlas Finans in 1995, and Asya Finans in $1996 .^{2}$ These intermediaries introduced a different banking model into the system with banning interest on deposits or loans. Instead, deposits were primarily invested into transactions based upon principles of markups (Murabaha) and leasing services (Ijhara). To distinguish the Islamic financial institutions from the conventional banks operating in Turkey, they were given the status of 'Special Finance Houses'. Despite being Islamic-compliant, such a name was given with the objective to soften their Islamic image and to resonate with the ideological sensibilities of the ruling administration. Initially, these institutions did not enjoy the same regulatory status as conventional banks, ${ }^{3}$ the Savings Deposit Insurance Fund (SDIF) did not cover their deposits, and they could not invest in government securities.

In the 1990s, otherwise known as the lost decade, the Turkish economy suffered severe setbacks from large and volatile international capital flows. The first unpleasant experience was due the 1991 Gulf War, which led to capital flow reversals and bank distress due to Turkey's closeness to Iraq, and the first major banking collapse occurred in 1994. ${ }^{4}$ Although the banking sector recovered quickly from the 1994 crisis, the economy in Turkey continued to face significant headwinds. In 1999, to reduce fiscal and monetary imbalances, the Turkish government launched an exchange rate-based stabilization (ERBS) program with the strong support of the IMF. Massive capital inflows contributed to the bubble in the stock market, the appreciation of the domestic currency, the widening of current account deficits, which in turn led to an excessive expansion in domestic credit. However, interest rates began to rise because of widening current account deficits and delays in the privatization program. With rates moving up, levered banks were forced to offload their treasury holdings at sale prices to maintain liquidity in the face of increasing financing costs. ${ }^{5}$ Taken together, all these factors caused capital reversals, implying a sharp increase in the overnight interest rates. In December 2000, an IMF rescue package was needed to ease the tensions in the financial markets, and a resemblance of stability was returned. However, the confidence in the disinflation program was completely lost, and the economy teetered on the brink of collapse. The aftermath of the 2001 crisis witnessed a significant drop in the number of conventional banks from more than 50 to just $33 .^{6}$

\footnotetext{
${ }^{2}$ We refer to Aysan et al. (2013) for an overview of the developments in the Turkish Islamic banking sector.

${ }^{3}$ Decree No. 83/7506, issued by the Council of Ministers, allowed Islamic banks to operate in Turkey. This decree, however, could just as easily be revoked by the same authority (Brown 2014).

${ }^{4}$ In order to contain budget deficits, the government introduced measures such as caps on Treasury bill rates, and shifted towards deficit financing through monetization. The curbing of interest rates in the weekly tenders for Treasury bills produced anxiety in financial markets and a loss of confidence in the government. The drop in interest rates caused a decline in the profits from uncovered arbitrage opportunities and banks started to close their open positions by buying foreign exchange in domestic markets. In order to contain the loss of foreign currency reserves, and to defend the Turkish lira, the Central Bank was forced to heavily intervene in the interbank market and raised the overnight rate to record levels. These developments undermined an already fragile system, and the banking sector faced panic withdrawals of bank deposits. In order to restore confidence and prevent further capital outflows, the government had to institute a blanket deposit guarantee.

${ }^{5}$ The problem was compounded in October and early November with rumors of malpractices of some nationalized banks. In October two more banks - Etibank and Bank Kapital - were brought under the management of the Savings Deposit and Insurance Fund (SDIF). Moreover, not met privatization targets, due to ideological differences within the ruling coalition, caused the IMF to postpone a scheduled fund transfer.

${ }^{6}$ The fierce turmoil, between President Ahmet N. Sezer and Prime Minister Ecevit in February 2001, completely agitated the financial markets. Because of the massive capital outflows, the overnight interest rates skyrocketed on February 21 and the Central Bank had no choice but to abandon the peg. We refer to Akyüz and Boratav (2003) for a detailed discussion about the development of the Turkish banking sector during the crisis.
} 
The financial crisis did not only affect conventional banks, but also the special finance houses. Amid the mounting foreign exchange crisis, on 10 February 2001, Ihlas Finans' license was revoked by the Banking Regulation and Supervision Agency (BRSA) after charges that it had siphoned off over $\$ 1$ billion to its parent holding company (The Economist 2001). Further, since Ihlas could not invest in government securities, it was exposed to a severe maturity mismatch. With the outbreak of the liquidity crisis, Ihlas' exposure led to its collapse when it experienced a traditional bank run on its deposits. Since there was no insurance to dissuade Islamic depositors from withdrawing their funds, it was feared that the panic would spread to depositors at other Islamic financial institutions. The remaining Islamic banks, however, proved to be resilient to the difficult operating environment. Another development in the same period was the purchase of Faisal Finans by the Turkish holding company Ülker, changing its name to Family Finans. Subsequently, in December 2005, Anadolu Finans and Family Finans were merged into Türkiye Finans, leaving the number of Shariah-compliant banks operating in Turkey to fall to four. ${ }^{7}$

The regulatory reform in Turkey actually started in June 1999 under Banks Act 4389. A new and independent regulatory authority, the BRSA, was established to oversee banking system stability. However, due to political disputes, the operationalization of the new agency was delayed until September 2000, when it became a little too late to intervene appropriately. ${ }^{8}$ The 1999 bank law also brought Islamic banks under the same regulatory umbrella as conventional banks. Although the reform sought to integrate the Islamic banks into the financial system, these banks were not made part of the conventional deposit insurance scheme but were merely given the right to create one of their own (Brown 2014). Further, the implementation of an Islamic deposit insurance scheme did not materialize until the collapse of Ihlas. The Islamic deposit insurance scheme provided insurance up to 50,000 TL for each deposit ownership in each bank, while the conventional insurance offered at that time an unlimited coverage. Furthermore, unlike the conventional system, which was managed by the government, the administration of the Islamic deposit insurance system was delegated to the 'Union of Private Finance Houses'. Membership to the Union was compulsory for all licensed Islamic banks, and as the scheme was backed by Islamic banks concerns about its Shariah-compliance were allayed. The operation of the system was funded by premiums received from Islamic banks, and these were assessed based on the amount of both demand and profit/loss participation accounts (i.e., $0.25 \%$ on the ending of quarterly balances ${ }^{9}$ ). This pioneering example was praised because of its conformity to Takaful principles, the Islamic version of

\footnotetext{
${ }_{7}$ In May 2015, Ziraat Participation Bank, was authorized by the country's banking regulator (BRSA) to start its operations as Turkey's first state-owned Islamic bank, increasing the number of Islamic banks to five.

${ }^{8}$ Although the institution of BRSA was not successful in preventing the crisis at the end of 2000, it is considered as the first of subsequent reforms in the regulation of the banking sector. In May 2001, the BRSA launched the Banking Sector Restructuring Program (BSRP) to recover fundamental fragilities in the banking sector, and for building a strong base for the system by clearing it from weak banks (see BRSA 2010). The structural reforms in the banking industry and the political stability after 2002 have facilitated a significant improvement in overall economic performance. In the period between 2002 and 2010, Turkey's public sector debt-to-GDP ratio firmly declined from $70 \%$ to $42 \%$, a ratio that is since 2004 consistently below the Maastricht criterion. The conducive economic environment in the period 2002-2007, with abundant global liquidity, also made Turkish treasury instruments very attractive, and massive capital inflows steadily helped to reduce interest rates.

${ }^{9}$ For purposes of completeness, Islamic banks with higher risk profiles could end-up paying $0.26 \%$ on their endof-quarter deposit liabilities.
} 
insurance, where members cooperate to pool resources in order to guarantee each other against loss or damage.

However, in December 2005, upon enactment of the Banking Act No. 5411, the dual deposit insurance system was revised and the management of the Islamic deposit insurance fund was transferred to the Savings Deposit Insurance Fund (SDIF). Following amendments to the banking law, 'Special Finance Institutions' were renamed as 'Participation Banks', which allowed them to integrate fully into the financial system. Premiums paid by Islamic banks to the SDIF were equalized with those of conventional banks, and the premium ratio had initially been calculated as of $0.15 \%$ of the deposit amount covered under the deposit insurance scheme (current and profit/loss participation accounts for Islamic banks and current and savings accounts for conventional banks). ${ }^{10}$ The Law, however, did not require to separate the premiums from conventional and Islamic banks, nor did it require the investment of premiums into Shariah-compliant instruments (Brown 2014). Since the Islamic fund is not separately managed anymore nor it is in accordance with the Shariah rules, serious concerns have been raised in the properly resolution of failed Islamic institutions.

Participation banking in Turkey has not traditionally made up a large portion of Turkey's finance sector due to the secular tradition of the republic. However, by becoming more and more like banks in both image and reality, they progressively gained acceptance among depositors and investors. Also, after the 2001 crisis, the ruling Justice and Development Party (AK Party) paved the way to the ascent of Islamic finance. As illustrated in Table 1, slowly but surely, and especially after the Banking Act of 2005, the sector has managed to increase its market share both on the credits and deposits segments of the financial industry.

\section{Data analysis and empirical strategy}

We collect an unbalanced panel of 48 commercial banks operating in Turkey from the various issues of Banks in Turkey published by the Banks Association of Turkey. This publication includes quarterly balance sheet and income statement information from 2002:4 to 2012:4. The fourth quarter of 2002 corresponds to the effective start of the Erdogan-era. Of the 48 conventional banks, 23 banks are branches of foreign banks or are classified as foreign subsidiaries (more than $50 \%$ of their shares are owned by non-residents), 22 banks are domestically owned commercial banks (more than $50 \%$ of their shares are owned by Turkish residents), and 3 are classified as state-owned deposit-taking banks (predominantly owned by the Turkish government). The Islamic bank data contains an unbalanced panel of 6 banks and is obtained from the Central Bank of the Republic of Turkey. ${ }^{11}$

As with most similar studies, we analyze both the price and quantity reactions to bank risk since this joint information allows us to better identify disciplining behavior. The use of this combined information will help us to disentangle depositor discipline from demand shifts (e.g., Ioannidou and de Dreu 2006; Karas et al. 2013). A positive relation between bank risk and

\footnotetext{
$\overline{{ }^{10} \text { From } 2009 \text { onward, the SDIF }}$ has implemented for both banking models a more risk weighted deposit insurance premiums with a premium ratio varying between $0.11 \%$ and $0.19 \%$. The maximum deposit insurance coverage for both Islamic and conventional bank deposits was set at 50,000 TL, but was in February 2013 doubled to 100,000 TL.

${ }^{11}$ For both Islamic as well as conventional banks, these figures includes adjustments for mergers \& acquisitions by generating a new bank after tracing such an event.
} 


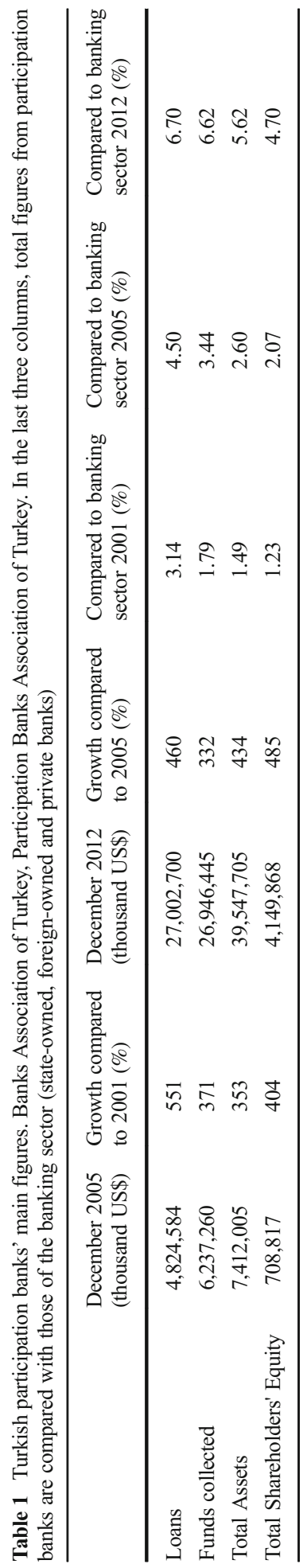


deposit rates could reflect a demand effect rather than discipline, with risky banks pursuing a more aggressive expansion strategy to meet new loan demand. But this would be discovered by looking at the quantity regression, where the relation between bank risk and deposit quantity would also be positive in case of a demand effect, and negative in case of true depositor discipline.

So far, most published studies have analyzed the differences in behavior to bank risk between insured and uninsured deposits and have ascribed behavioral differences to the presence of insurance. In their approach, however, it cannot be dismissed that other depositor groupspecific characteristics may possibly explain the observed differences as well. Other studies provide empirical evidence on the incentive impact of deposit insurance by comparing the behavior of a particular depositor group by looking at the before and after deposit insurance introduction. But their approach cannot reject the possibility that the results are driven by other time specific unobservable characteristics. The difference-in-differences approach allows us to study the effect of treatment, in this case the unification of the dual deposit insurance system, by comparing the depositor sensitivity to risk of the treatment group (i.e., Islamic banks) pre- and post-treatment relative to the depositor sensitivity to risk of the control group (i.e., conventional banks) pre- and post-treatment. By comparing changes, we control for time-invariant characteristics that might affect Islamic and conventional bank depositors differently and for time-varying factors that might affect them in a similar fashion.

Our identification strategy is the most related to Karas et al. (2013). They employ a similar difference-in-differences methodology to identify the differential impact of deposit insurance on the behavior of insured households and uninsured firms and find evidence that insurance diminishes the insured depositors' sensitivity to bank risk.

We employ the following reduced-form difference-in-differences models:

$\mathrm{DEPG}_{\mathrm{i}, \mathrm{j}, \mathrm{t}}=\alpha_{\mathrm{i}}+\alpha_{\mathrm{j}, \mathrm{t}}+\alpha_{1} * \mathrm{X}_{\mathrm{i}, \mathrm{t}-1}+\alpha_{2} * \mathrm{X}_{\mathrm{i}, \mathrm{t}-1} * \mathrm{ISL}+\alpha_{3} * \mathrm{X}_{\mathrm{i}, \mathrm{t}-1} * \mathrm{REF}+\alpha_{4} * \mathrm{X}_{\mathrm{i}, \mathrm{t}-1} * \mathrm{ISL} * \mathrm{REF}+\alpha_{5} * \mathrm{C}_{\mathrm{i}, \mathrm{t}}+\varepsilon_{\mathrm{i}, \mathrm{j}, \mathrm{t}}$

$\operatorname{RDEP}_{\mathrm{i}, \mathrm{j}, \mathrm{t}}=\beta_{\mathrm{i}}+\beta_{\mathrm{j}, \mathrm{t}}+\beta_{1} * \mathrm{X}_{\mathrm{i}, t-1}+\beta_{2} * \mathrm{X}_{\mathrm{i}, t-1} * \mathrm{ISL}+\beta_{3} * \mathrm{X}_{\mathrm{i}, t-1} * \mathrm{REF}+\beta_{4} * \mathrm{X}_{\mathrm{i}, t-1} * \mathrm{ISL} * \mathrm{REF}+\beta_{5} * \mathrm{C}_{\mathrm{i}, \mathrm{t}}+\mu_{\mathrm{i}, \mathrm{j}, \mathrm{t}}$

Where $I S L=1$ for Islamic banks and $I S L=0$ for conventional banks. The variable $R E F$ is a dichotomous variable for the post-treatment period, i.e., after the unification of the insurance system in 2005Q4. From the perspective of depositors, we can fairly claim that the deposit insurance reform constitutes an exogenous change and its impact only applies to Islamic banks but not to conventional banks. The reaction variables are the traditional measures used in the depositor discipline literature. The dependent variable in Eq. 1 is the first difference of the log of deposits of bank type $j$ (Islamic or conventional) for bank $i$ during period $t$, and the dependent variable in Eq. 2 is the quarterly expenses for bank deposits divided by total deposits of type $j$ for bank $i$ during period $t$. For both Islamic and conventional banks, according to the market discipline hypothesis, the return on deposits should in principle be a reflection of the risk profile.

The $X_{i, t-1}$ represents a matrix of bank fundamentals that might be of interest to depositors concerned about bank safety. This vector contains capitalization, our primary indicator of bank-level risk, bank liquidity, and non-performing loans. These variables are included with a one-quarter lag to account for the delay in publication. 
The CAP variable is measured as the capital-to-assets ratio. The $L I Q$ and $N P L$ variables are calculated as liquid assets to total assets, and the ratio non-performing loans to assets, respectively. Although we focus on the sensitivity of depositors to bank capitalization, we estimate the most flexible specification by integrating each of these fundamentals directly (coefficient $\alpha_{1}$ in Eq. $1 / \beta_{1}$ in Eq. 2) as well as with three separate interaction terms (coefficients $\alpha_{2}, \alpha_{3}$ and $\alpha_{4}$ in Eq. $1 / \beta_{2}, \beta_{3}$, and $\beta_{4}$ in Eq.2) in each difference-in-differences specification (Eq. 1 or Eq. 2).

Our primary measure of a bank's risk level is its capital-to-assets ratio. Following the introduction of the 1988 Basel Accord and the 1996 Market Risk Amendment, the importance of bank capital buffers to financial safety has been emphasized and capital management has become the main channel through which banks manage their risk of insolvency (Nier and Baumann 2006). Further, more than any other measure, the capital ratio is extensively used as a proxy for bank risk taking in market discipline studies, in both developed and emerging market economies (e.g., Hannan and Hanweck 1988; Park and Peristiani 1998; Martinez Peria and Schmukler 2001; Karas et al. 2013; Disli et al. 2013; Berger and Turk-Ariss 2014). We also refer to Disli and Schoors (2013) and Disli et al. (2013) who found that only bank capital proved to be unambiguously leading to depositor discipline in the Turkish conventional banking market. From the perspective of depositors, this simple but powerful indicator mitigates information asymmetries since a bank's decision to hold more capital subject its owners to a greater loss in case of failure. As holding capital encourages banks to undertake less risk, depositors will reward these banks by supplying more funds at lower deposit rates.

Evidence of depositor discipline requires $\alpha_{1}>0$ and $\beta_{1}<0$ with increased bank capitalization for conventional banks in the pre-treatment period. The slope parameters $\alpha_{2}$ and $\beta_{2}$ seize the difference in means between Islamic and conventional banks before the treatment takes place. If the signs of $\alpha_{2}$ and $\beta_{2}$ are similar to the signs of $\alpha_{1}$ and $\beta_{1}$, respectively, Islamic depositors are more vigilant to bank risk than their conventional counterparts. If on the other hand, $\alpha_{2}$ and $\beta_{2}$ have opposite signs to that of $\alpha_{1}$ and $\beta_{1}$, respectively, Islamic depositors are not as much sensitive to bank risk as conventional depositors. The parameters $\alpha_{3}$ and $\beta_{3}$ capture for the conventional banking market the change in depositor sensitivity in the unified deposit insurance period. The coefficients $\alpha_{4}$ and $\beta_{4}$ quantify the additional shift in the sensitivity of Islamic depositors after the treatment.

The $C_{i, t}$ contains other bank specific controls potentially affecting the reaction variables. The Bank size variable is calculated as the natural logarithm of total assets. As a measure for institutional maturity, we define Bank age as the natural logarithm of quarter-years. The variable Branch size is the average number of employees per branch and is used as a metric of bank service quality. Since listed banks expose themselves more to public scrutiny, we also control for this and use a dummy variable which equals to 1 when banks are listed in the Istanbul Stock Exchange (Borsa Istanbul).

We estimate a model using bank-fixed effects, $\alpha_{i}$, for the quantity reaction, and $\beta_{i}$, for the return reaction to control for unobserved characteristics across banks. Furthermore, in all specifications, we include quarter dummy variables per bank type $j$ (Islamic or conventional) to account for nation-wide shocks that may have a different effect on the two types of depositors (i.e., $\alpha_{j, t}$ in the deposit growth equation and $\beta_{j, t}$ in the price equation). 
Table 2 provides summary statistics on variables used in this analysis. The table compares the treatment group of Islamic banks to the control group of conventional banks for the period before as well as after the deposit insurance reform. Although the difference diminished in time, we ascertain that Islamic banks were able to attract more deposits than their conventional counterparts. Interestingly, they were able to do so even though they offered lower returns on deposits. In both periods, Turkish Islamic banks exhibit poor fundamentals vis-à-vis their conventional peers in terms of bank capitalization $(C A P)$ and liquidity positions $(L I Q)$. It seems, however, that Islamic banks achieved better loan quality $(N P L)$ than conventional banks. Conventional banks have on average more personnel per branch than Islamic banks for both periods. Finally, after the reform, two Islamic banks have been listed on the Istanbul Stock Exchange, while there were no listed Islamic banks in the period before.

\section{Empirical results}

Table 3 presents the results from the difference-in-differences estimations. Columns (1-4) exhibit the estimation results of Eq. 1; columns (5-8) refer to the estimation results of Eq. 2. To test whether our results are sensitive to alternative sample compositions, for each equation we produce four sets of estimates. Columns (1) and (5) report the results for all banks with different ownership types. In columns (2) and

Table 2 Summary statistics. The table reports summary statistics of bank-specific variables with each observation representing a measure for a single bank in a specific quarter. The DEPG is calculated as the first difference of the log of deposits. The RDEP represents the implicit returns on deposits, calculated as the quarterly deposit expenses divided by total bank deposits. The bank fundamentals are represented by CAP, NPL and LIQ. The CAP is the book value of equity to total assets. The LIQ is equal to liquid assets (cash and central bank reserves) to total assets. The NPL is ratio of loans under follow-up to total credits. The control-vector contains Bank size, Bank age, Branch size and Listed. The Bank size variable is computed as the natural logarithm of total assets. The Bank age variable is the natural logarithm of quarter-years the bank exists. The Branch size variable is the average number of employees per branch. The Listed variable equals to 1 when banks are listed in the Istanbul Stock Exchange (Borsa Istanbul)

\begin{tabular}{|c|c|c|c|c|c|c|c|c|}
\hline & \multicolumn{4}{|c|}{ 2002Q4-2005Q3 } & \multicolumn{4}{|c|}{ 2005Q4-2012Q4 } \\
\hline & \multicolumn{2}{|c|}{ Conventional Banks } & \multicolumn{2}{|c|}{ Islamic Banks } & \multicolumn{2}{|c|}{ Conventional Banks } & \multicolumn{2}{|c|}{ Islamic Banks } \\
\hline & Mean & Std. Dev. & Mean & Std. Dev. & Mean & Std. Dev. & Mean & Std. Dev. \\
\hline DEPG & 0.026 & 0.385 & 0.085 & 0.075 & 0.052 & 0.392 & 0.064 & 0.050 \\
\hline RDEP & 0.030 & 0.073 & 0.021 & 0.005 & 0.023 & 0.145 & 0.017 & 0.006 \\
\hline CAP & 0.188 & 0.146 & 0.114 & 0.029 & 0.193 & 0.180 & 0.119 & 0.021 \\
\hline NPL & 0.127 & 0.222 & 0.108 & 0.063 & 0.061 & 0.155 & 0.041 & 0.015 \\
\hline LIQ & 0.235 & 0.217 & 0.145 & 0.061 & 0.202 & 0.211 & 0.209 & 0.090 \\
\hline Bank size & 14.119 & 2.135 & 13.936 & 0.399 & 15.283 & 2.234 & 15.747 & 0.615 \\
\hline Bank age & 4.662 & 0.786 & 4.007 & 0.366 & 4.890 & 0.645 & 4.354 & 0.301 \\
\hline Branch size & 29.595 & 21.875 & 18.338 & 3.504 & 27.945 & 20.152 & 20.562 & 2.912 \\
\hline Listed & 0.299 & 0.458 & 0.000 & 0.000 & 0.399 & 0.490 & 0.422 & 0.496 \\
\hline
\end{tabular}




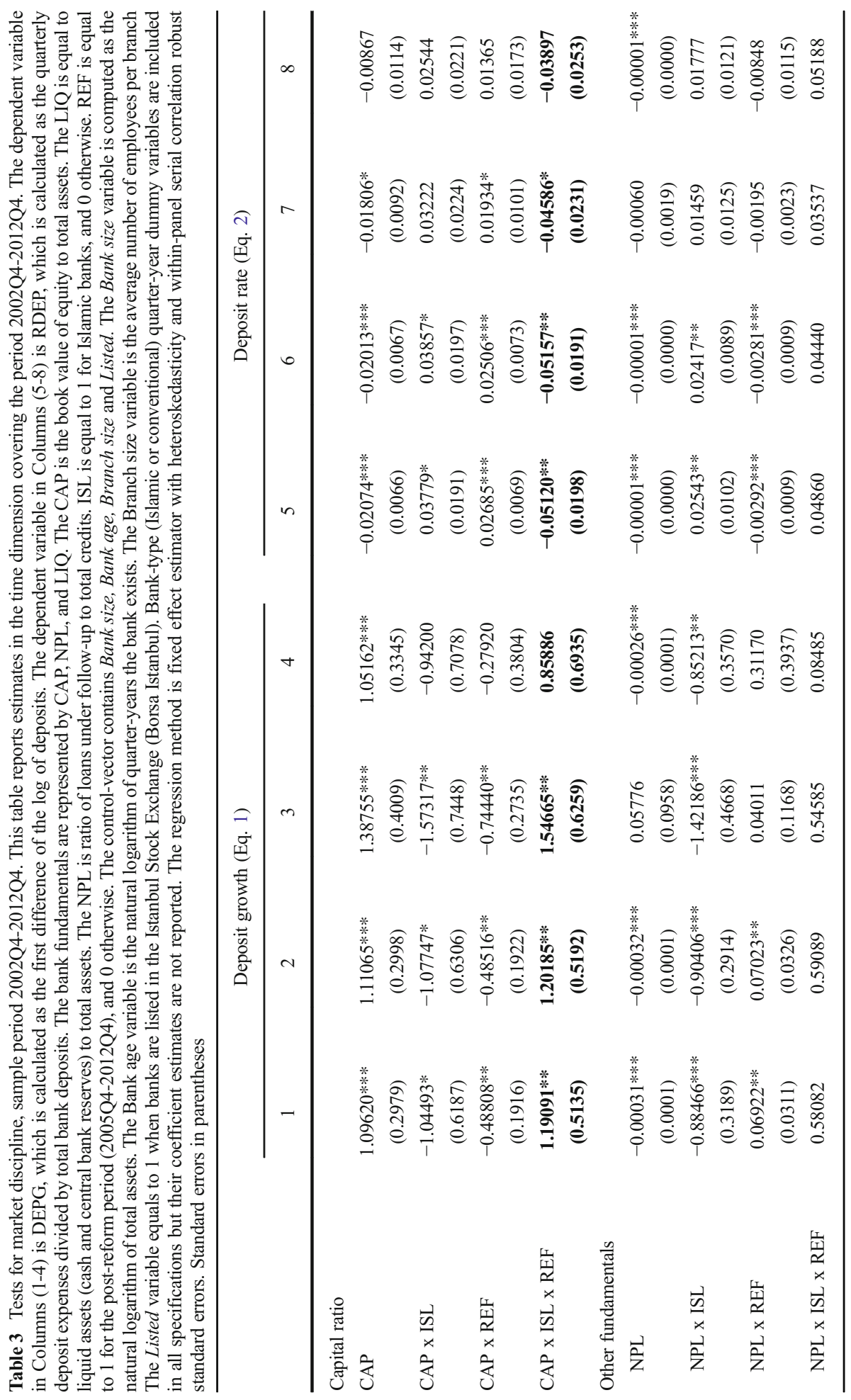




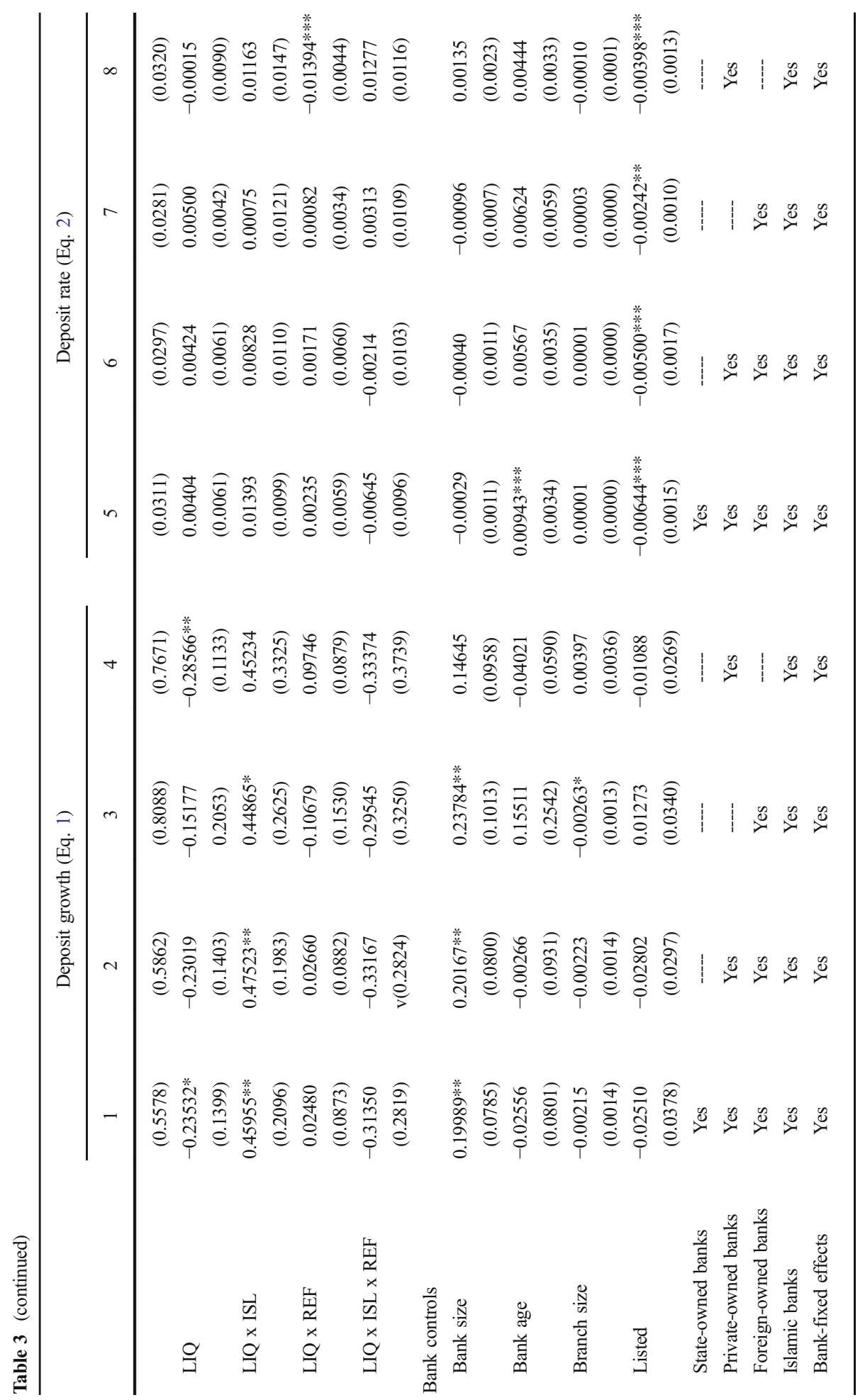




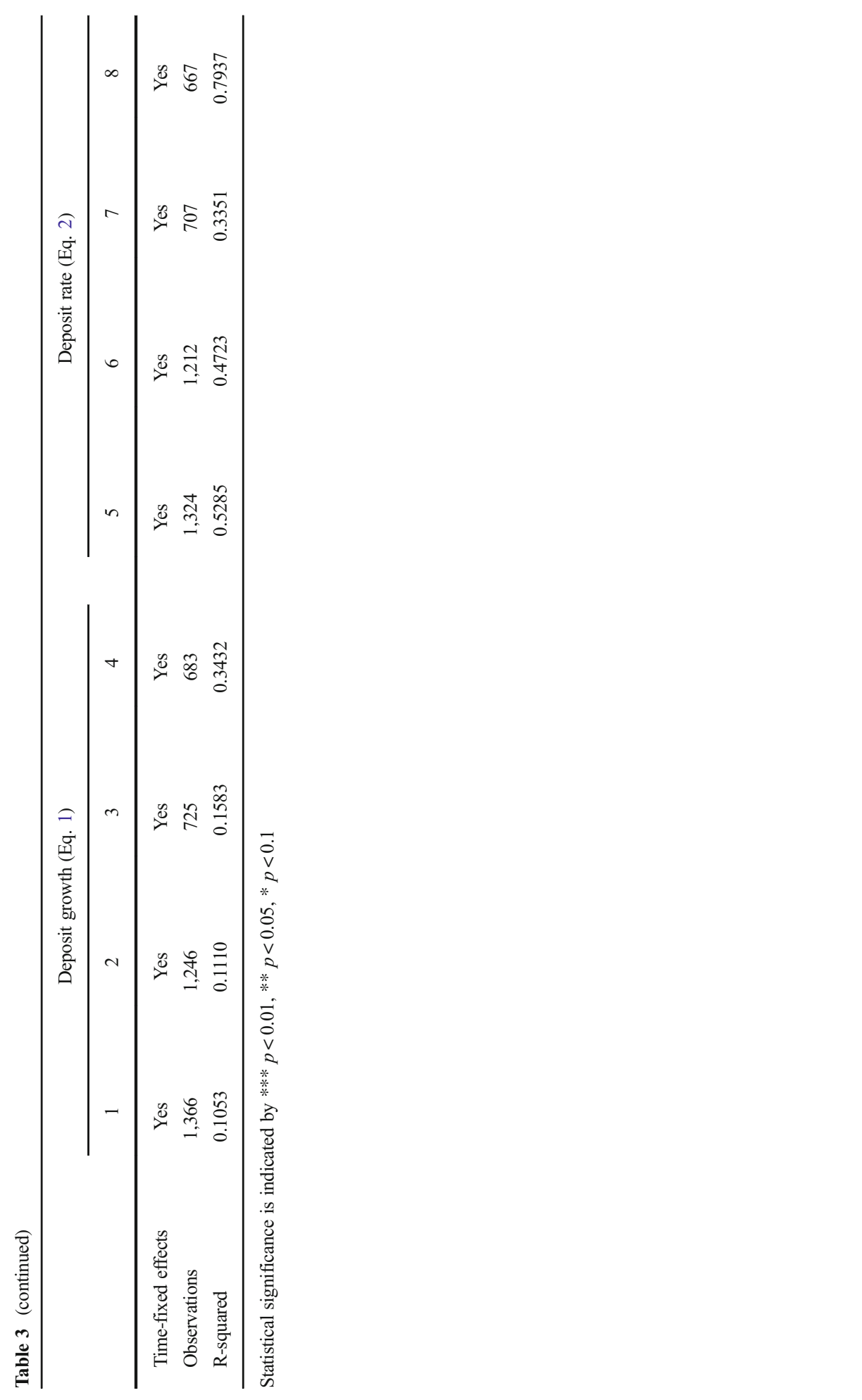


(6) we exclude state-owned banks since they provide depositors weaker incentives for monitoring and disciplining (Caprio and Honohan 2004). Columns (3) and (7) restrict the sample to foreign-owned banks as a control group, while in columns (4) and (8) compare the behavior of Islamic depositors to that of their privately-owned peers.

Prior to the unified deposit insurance implementation, in general we observe that depositors of conventional banks were sensitive to bank capitalization $(C A P)$. An increase in the capital ratio is associated with higher deposit growth $\left(\alpha_{1}>0\right.$ and statistically significant for different sample selections) and lower deposit rates $\left(\beta_{1}<0\right.$ and statistically significant for different sample selections except for column 8), which provides direct evidence of depositor discipline. ${ }^{12}$ As to whether Islamic depositors were more or less sensitive to bank capitalization than conventional depositors prior to the deposit insurance reform (see the coefficient estimate of CAP x ISL), the evidence suggests that quantity sensitivity to capitalization was annihilated (i.e., $\alpha_{1}+\alpha_{2}$ ). The parameter estimates of $\alpha_{3}$ and $\beta_{3}$ reveal the change in depositor sensitivity in the unified deposit insurance scheme period for conventional banks (coefficient estimate of $C A P$ x $R E F)$.

In what follows, given our primary focus, we concentrate on the main coefficients of interest $\left(\alpha_{4}\right.$ and $\beta_{4}$ ). In the quantity equation, through different samplings (except in columns 4 and 8), we observe that the difference-and-differences coefficient $\left(\alpha_{4}\right)$ is consistently positive and highly significant. We also find that $\beta_{4}$ in general enters the deposit rate equation with negative coefficients. These findings suggest that in general the sensitivity of Islamic bank depositors, relative to conventional depositors, have increased substantially after the reform. Alternatively, we might describe the coefficients $\alpha_{3}$ and $\beta_{3}$ as capturing the commonly felt impact of depositor insurance reform on depositor vigilance, whereas the difference-in-difference coefficients seize the differential impact on the vigilance of Islamic depositors. In sum, our results reveal that, in the pre-reform period, conventional bank depositors were more sensitive to bank capitalization as predicted by the market discipline theory: banks with lower capital ratios attracted fewer deposits while they paid higher risk premiums. On the other hand, Islamic banks were in the same period not disciplined at all. The deposit insurance reform, however, consistently produced more sensitive Islamic depositors to bank risk. ${ }^{13}$

Confirming the importance of the capital ratio, other bank fundamentals (NPL and LIQ), and their interactions with ISL and/or REF, do not allow us to draw clear conclusions concerning their influence on market discipline. ${ }^{14}$ Turning to our control variables, larger banks (Bank size) do benefit from too-big-to fail effects as they on

\footnotetext{
${ }^{12}$ Conversely, depositors will punish banks with a lower capital ratio by decreasing the supply of funds, i.e., raising the average yield on deposits and reducing the quantity of deposits.

${ }^{13}$ The estimation results for the sample composition of private and Islamic banks, columns 4 and 8 of Table 3 , reveal that while the signs of the estimated coefficients for the capital ratio and for its interactions are similar to those of alternative sample compositions, most of them are not statistically significant.

${ }^{14}$ Although conventional banks with high performing loans (NPL) face deposit withdrawals, it also appears to decrease the interest rate that depositors demand from these banks. A similar finding was observed in the Columbian banking sector (Barajas and Steiner 2000). In the post-reform period, our findings indicate that the conventional deposit growth sensitivity to NPL has been reversed. On the other hand, albeit heavily reduced in the post-reform period, Islamic depositors were sensitive to non-performing loans in the manner predicted by the market discipline hypothesis. The effect of liquidity $(L I Q)$ on the reaction of depositors, Islamic as well as conventional, is not consistent with the market discipline hypothesis.
} 
average succeed in attracting more deposits while they do not pay higher returns on deposits. We do not find evidence that older banks (Bank age) produce advantage in terms of deposits and interest rates compared to their younger counterparts. Further, bank service quality (Branch size) does not seem to influence deposit flows nor the expenses on deposits, while the deposit expenses of listed banks (Listed) were on average lower.

\section{Banking crisis, dual deposit insurance and market discipline}

\subsection{Before and after the $2001 \mathrm{Q} 1$ crisis}

Turkey's relatively large and historically troubled conventional banking sector had been covered by deposit insurance since 1983; as we have noted, combined with problems of insider lending, weak monitoring and control mechanism, provision of implicit and explicit government guarantees had left the banking sector in a particularly vulnerable position. Although Islamic banks were not much affected by the 1994 financial crisis, the 2001 crisis shook also this segment of the industry. In the wake of the 2001 banking crisis, Ihlas Finans, the then largest finance house, faced a run on its deposits. In February 2001, the BRSA revoked the operating license of Ihlas Finans on the grounds that it failed to fulfill its liabilities. However, unlike the conventional deposits, the deposits of Islamic banks did not enjoy insurance coverage with the rationale that profit-and-loss accounts involved no guarantee of return (Starr and Yilmaz 2007). ${ }^{15}$ In a way, the actual creation of the Islamic deposit insurance scheme right after the collapse of Ihlas provides us a second natural experiment: both banking models were affected by the crisis with the difference being that conventional banks enjoyed deposit insurance, whereas Islamic banks only did so right after the collapse of Ihlas.

We first estimate the sensitivity of deposit flows to bank financial conditions, allowing for different sensitivities across the two banking models and two distinct periods: before and after the 2001Q1 crisis. Since expenses on Islamic deposit accounts were not available before 2002, we cannot estimate the equivalent price equation. Specifically, we estimate the following panel specification:

$$
\begin{aligned}
\operatorname{DEPG}_{\mathrm{i}, \mathrm{j}, \mathrm{t}}= & \alpha_{\mathrm{i}}+\alpha_{\mathrm{j}, \mathrm{t}}+\alpha_{1} * \mathrm{X}_{\mathrm{i}, \mathrm{t}-1}+\alpha_{2} * \mathrm{X}_{\mathrm{i}, \mathrm{t}-1} * \mathrm{ISL}+\alpha_{3} * \mathrm{X}_{\mathrm{i}, \mathrm{t}-1} * \mathrm{CRIS} \\
& +\alpha_{4} * \mathrm{X}_{\mathrm{i}, \mathrm{t}-1} * \text { ISL } * \mathrm{CRIS}+\alpha_{5} * \mathrm{C}_{\mathrm{i}, \mathrm{t}}+\varepsilon_{\mathrm{i}, \mathrm{j}, \mathrm{t}}
\end{aligned}
$$

As in Eq. 1, the dependent variable is the first difference of the log of deposits of bank type $j$ for bank $i$ during period $t$. The right-hand side variables are the same as in Section 4.2., with the exception that the deposit insurance reform dummy variable $(R E F)$ is now replaced by the financial crisis (CRIS) dummy variable. The financial crisis dummy variable takes the value of 1 for the period after the collapse of the banking sector (2001Q1 and thereafter), and 0 otherwise. The coefficient $\alpha_{1}$ capture the sensitivity of deposit growth to bank capitalization for conventional banks before the financial crisis. The slope parameter $\alpha_{2}$ represents the difference in means between Islamic

\footnotetext{
${ }^{15}$ The liquidation process of Ihlas would drag on and, as of today, has still not been settled in full. Profit and loss sharing participation accounts were fourth in line for repayment after debts owed to the government, personnel payments and current account debts. On December 31, 2013, 20,780 depositors were still waiting to be serviced. Further details about the payout schedule can be found at http://www.ifk.com.tr/ (last visited on May 25, 2015).
} 
and conventional banks before the crisis. The coefficient $\alpha_{3}$ seize the effect of a macroeconomic shock - that is, the banking crisis - on the vigilance of conventional (wholly) and Islamic depositors (partly, in conjunction with $\alpha_{4}$ ). The coefficient $\alpha_{4}$ (the difference-in-differences coefficient) captures the differential effect of Islamic deposit insurance on the vigilance of Islamic depositors.

Since the outbreak of the financial crisis occurred concurrently with the introduction of the Islamic deposit insurance scheme, we are not able to disentangle their potential opposing effects on market discipline. However, it might be possible that in the immediate aftermath of the crisis, the wake-up call effects might transcend the numbing effect of the newly instituted deposit insurance scheme. Therefore, we estimate the model for two sample periods: 1998Q1-2002Q3 (the period before AK Party came into power) and 1998Q1-2005Q3 (the period before the unification of deposit insurance schemes).

Table 4 reports the estimation results of Eq. (3). Columns (1)-(4) present the results for the 1998Q1-2005Q3 sample period, whereas Columns (5)-(8) display the results for the shorter sample period (1998Q1-2002Q3). We estimate the most flexible specification with capital $(C A P)$, loan quality $(N P L)$, and liquidity $(L I Q)$ and full set of interactions. In order to facilitate the interpretation of the results, however, we only report the coefficient estimates of $C A P$ and its interactions with ISL and/or CRIS since the other fundamental variables do not allow us to draw meaningful conclusions concerning their influence on market discipline. ${ }^{16}$ As in Table 3, each column in both panels reflect the estimation results for alternative sample compositions. Our results in general indicate that, prior to the outbreak of the financial crisis, conventional $\left(\alpha_{1}>0\right)$ as well as Islamic $\left(\alpha_{1}+\alpha_{2}>0\right)$ depositors were sensitive to bank capitalization. Even though the conventional depositors were backed by a deposit insurance fund, they continued to impose market discipline on their banks. This finding is in line with the results of Martinez Peria and Schmukler (2001) who reported that even insured depositors may respond to bank risk if they are concerned about the insurance fund solvency, or that depositors still feared costs related to the recovery of deposits in case of failure (i.e. costs due to late payments and the foregone interest earnings). Likewise, for a sample of banks in CEEC countries, the recent study of Hasan et al. (2013) found that global financial crisis did not alter the sensitivity of capital flows to bank risk. ${ }^{17}$

Before the crisis, although somewhat weakened when considering the shorter sample period, Islamic depositors behaved in accordance to the market discipline hypothesis. More importantly, in the post-crisis period, with the introduction of an Islamic deposit insurance scheme, and independent of the examined sample period, the capital ratio lost its indicative power to discipline Islamic banks. ${ }^{18}$ Our findings indicate that the wake-up call effect of Ihlas' failure on Islamic depositors was

\footnotetext{
${ }^{16}$ Full results are available upon request. Disli et al. (2013) and Karas et al. (2013) employed a similar projection of their results in their analyses of market discipline in the Turkish and Russian banking sector, respectively.

${ }^{17}$ Fueda and Konishi (2007) show that depositor sensitivity in Japan was most significant in the period 19972001 despite the presence of a blanket guarantee. Likewise Forssbæck (2011), who analyzed several hundred banks worldwide over the period 1995-2005, could not find evidence of increased depositor sensitivity during financial crises.

${ }^{18}$ A notable exception is the sample composition of foreign and Islamic banks (columns 3 and 7 of Table 4): although the sign of the coefficient of CAP x ISL x CRIS is similar to those of other sample compositions, it is not statistically significant.
} 


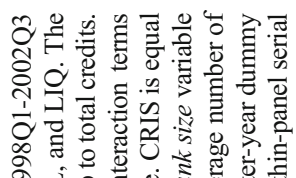

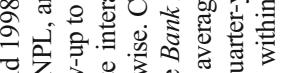

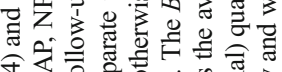

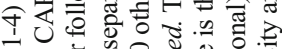

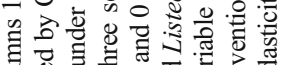

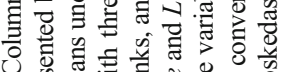

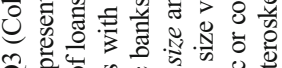

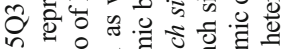

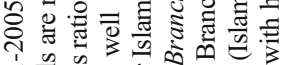

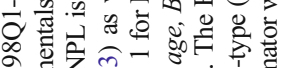

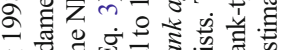

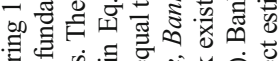

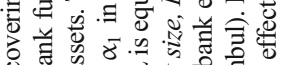

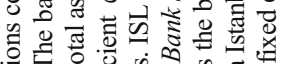

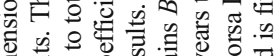

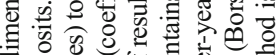

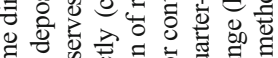

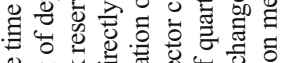
品

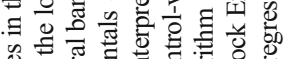

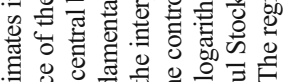

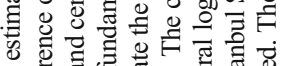

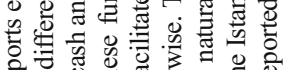

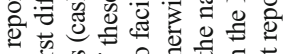

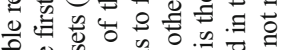

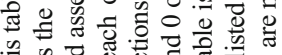

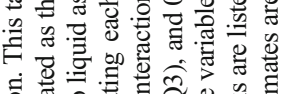

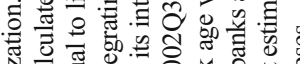

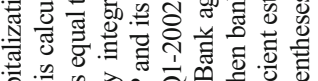

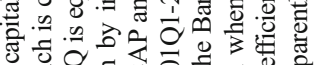

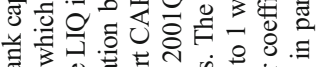

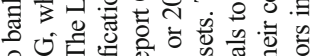

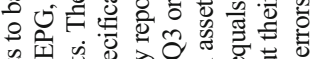

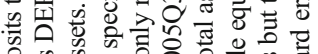
.

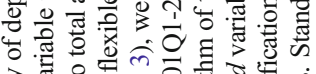

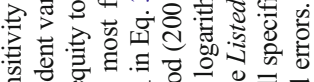

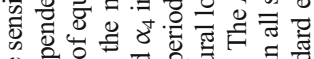

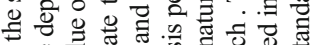

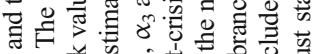

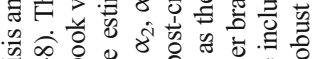

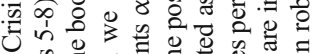
-

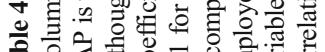

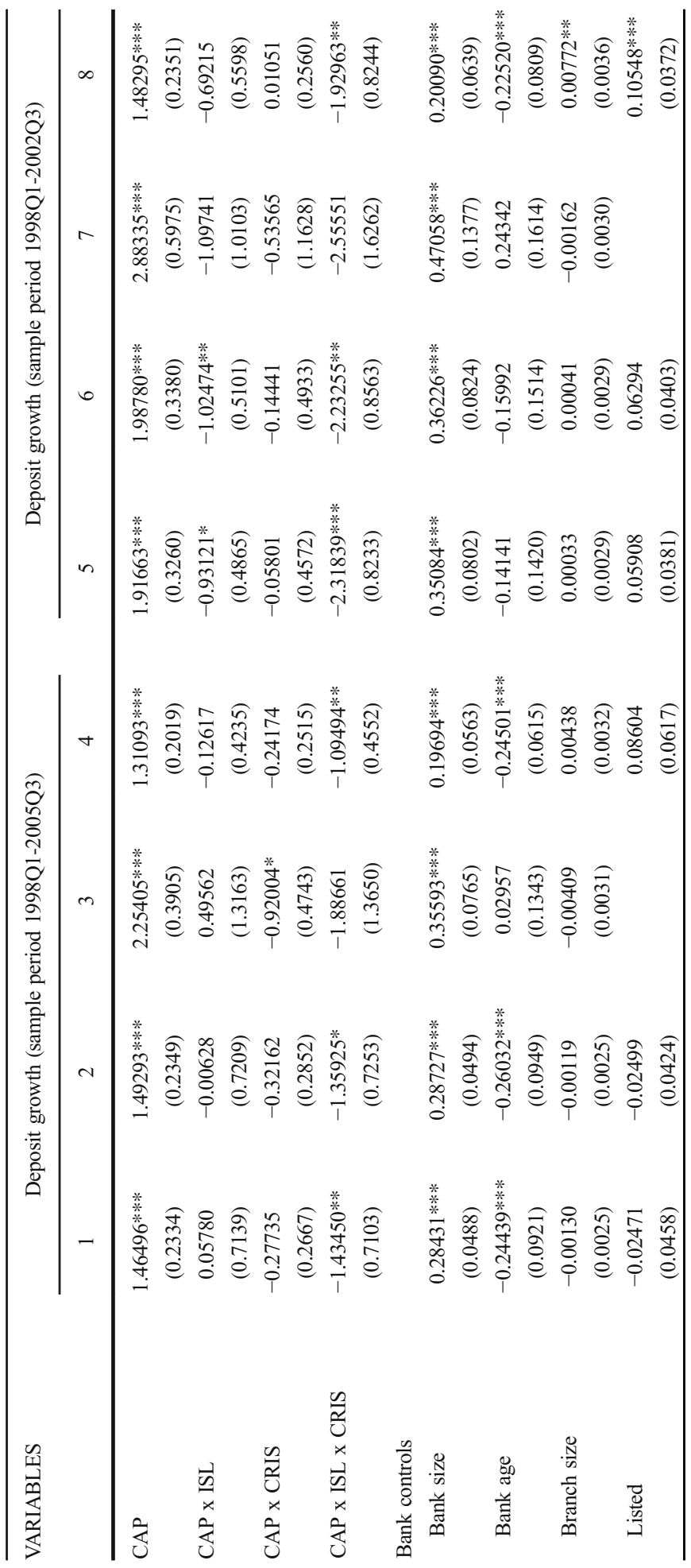




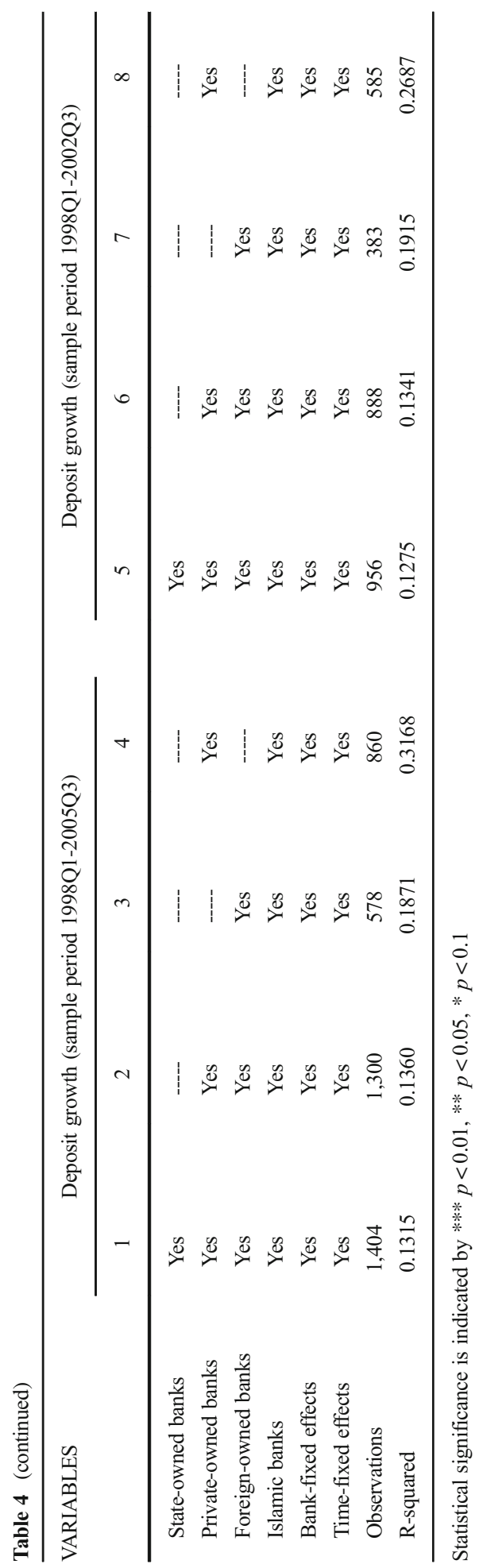


substantially muted with the creation of an Islamic deposit insurance scheme. ${ }^{19}$ Furthermore, at the onset of the failure of Ihlas, Starr and Yilmaz (2007) show that the deposit levels of a competing Islamic bank quickly recovered after an initial decline. Rather than raising doubts about the Islamic banking conduct, it appears that Islamic depositors perceived the Ihlas case as an isolated event. ${ }^{20}$ This finding confirms our previous observation that market discipline was not present in the Islamic banking segment before the unification of deposit insurance schemes, i.e., in the period where the Islamic deposit insurance scheme was instituted.

\subsection{Full sample period}

In this section, by making use of the full sample period, we integrate the two previous analyses into one. Specifically, we estimate the sensitivity of deposit growth to bank risk factors by looking at the differences in sensitivities across the two depositor groups and three distinct periods: before the 2001Q1 crisis, the 2001Q1 (outbreak of the crisis) and 2005Q3 (before deposit insurance reform) period and the post-reform period. For this purpose, we estimate the following regression model:

$$
\begin{aligned}
\mathrm{DEPG}_{\mathrm{i}, \mathrm{j}, \mathrm{t}}= & \alpha_{\mathrm{i}}+\alpha_{\mathrm{j}, \mathrm{t}}+\alpha_{1} * \mathrm{X}_{\mathrm{i}, \mathrm{t}-1}+\alpha_{2} * \mathrm{X}_{\mathrm{i}, \mathrm{t}-1} * \mathrm{P} 2+\alpha_{3} * \mathrm{X}_{\mathrm{i}, \mathrm{t}-1} * \mathrm{P} 3+\alpha_{4} * \mathrm{X}_{\mathrm{i}, \mathrm{t}-1} * \mathrm{ISL} \\
& +\alpha_{5} * \mathrm{X}_{\mathrm{i}, \mathrm{t}-1} * \mathrm{ISL} * \mathrm{P} 2+\alpha_{6} * \mathrm{X}_{\mathrm{i}, \mathrm{t}-1} * \mathrm{ISL} * \mathrm{P} 3+\alpha_{5} * \mathrm{C}_{\mathrm{i}, \mathrm{t}}+\varepsilon_{\mathrm{i}, \mathrm{j}, \mathrm{t}}
\end{aligned}
$$

with the dependent variable being the first difference of the log of deposits of bank type $j$ for bank $i$ during period $t$. The right-hand side variables include the same bank fundamentals $(X)$ and bank controls $(C)$ as in the previous (sub)sections. While the period before the 2001Q1 crisis serves as a reference period, we define $P 2$ as equal to 1 for the period 2001Q1-2005Q3 and 0 otherwise, P3 is equal to 1 for the period 2005Q4 to 2012Q4 and 0 otherwise. The differences in deposit flow sensitivities to bank risk across the two depositor groups and the three periods are summarized as follows:

\begin{tabular}{lcc}
\hline & Conventional Banks & Islamic Banks \\
Period 1 (1998Q1-2000Q4) & $\alpha_{1}$ & $\alpha_{1}+\alpha_{4}$ \\
Period 2 (2001Q1-2005Q3) & $\alpha_{1}+\alpha_{2}$ & $\left(\alpha_{1}+\alpha_{4}\right)+\left(\alpha_{2}+\alpha_{5}\right)$ \\
Period 3 (2005Q4-2012Q4) & $\alpha_{1}+\alpha_{3}$ & $\left(\alpha_{1}+\alpha_{4}\right)+\left(\alpha_{3}+\alpha_{6}\right)$ \\
\hline
\end{tabular}

The estimation results are reported in Table 5. As in the previous tables, the different columns represent different sample compositions. ${ }^{21}$ Prior to the crisis, in Period 1, we observe a positive relationship between deposit flows and bank capital for both modes of banking, and in fact no difference in market disciplining between them (the coefficient $\alpha_{1}$ of CAP is positive, whereas the coefficient $\alpha_{4}$ of the

\footnotetext{
${ }^{19}$ We refer to Cubillas et al. (2012) and Berger and Turk-Ariss (2014) for evidence about the weakening impact of government intervention on market discipline.

${ }^{20}$ Likewise no bank panic occurred when banking regulators took over management of Bank Asya in February 2015.

${ }^{21}$ In order to facilitate the interpretation of the results, we only report the coefficient estimates of $C A P$ and its interactions with ISL and/or time frame dummies (Period 2 and Period 3) since the other fundamental variables do not allow us to draw clear conclusions concerning their influence on market discipline.
} 
Table 5 Crisis, deposit insurance reform, and the sensitivity of deposits to bank capitalization. This table reports estimates in the time dimension covering 1998Q1-2012Q4. The dependent variable is DEPG, which is calculated as the first difference of the log of deposits. The bank fundamentals are represented by CAP, NPL, and LIQ. The CAP is the book value of equity to total assets. The LIQ is equal to liquid assets (cash and central bank reserves) to total assets. The NPL is ratio of loans under follow-up to total credits. Although we estimate the most flexible specification by integrating each of these fundamentals directly (coefficient $\alpha_{1}$ in Eq. 3) as well as with three separate interaction terms (coefficients $\alpha_{2}, \alpha_{3}$ and $\alpha_{4}$ in Eq. 3), we only report CAP and its interactions to facilitate the interpretation of results. ISL is equal to 1 for Islamic banks, and 0 otherwise. While the period before the 2001Q1 crisis serve as a reference period, we define PERIOD2 as equal to 1 for the period 2001Q1-2005Q3 and 0 otherwise, and PERIOD3 as equal to 1 for the period 2005Q4 to 2012Q4 and 0 otherwise. The controlvector contains Bank size, Bank age, Branch size and Listed. The Bank size variable is computed as the natural logarithm of total assets. The Bank age variable is the natural logarithm of quarter-years the bank exists. The Branch size variable is the average number of employees per branch. The Listed variable equals to 1 when banks are listed in the Istanbul Stock Exchange (Borsa Istanbul). Bank-type (Islamic or conventional) quarter-year dummy variables are included in all specifications but their coefficient estimates are not reported. The regression method is fixed effect estimator with heteroskedasticity and within-panel serial correlation robust standard errors. Standard errors in parentheses

\begin{tabular}{|c|c|c|c|c|}
\hline \multirow[t]{2}{*}{ VARIABLES } & \multicolumn{4}{|c|}{ Deposit growth (sample period 1998Q1-2012Q4) } \\
\hline & 1 & 2 & 3 & 4 \\
\hline CAP & $\begin{array}{c}1.27116^{* * * *} \\
(0.2197)\end{array}$ & $\begin{array}{c}1.33225 * * * \\
(0.2275)\end{array}$ & $\begin{array}{c}2.09319 \text { *** } \\
(0.4206)\end{array}$ & $\begin{array}{c}1.14524 * * * \\
(0.1800)\end{array}$ \\
\hline CAP x PERIOD2 & $\begin{array}{r}-0.30974 \\
(0.2345)\end{array}$ & $\begin{array}{c}-0.36737 \\
(0.2517)\end{array}$ & $\begin{array}{c}-0.83291 * \\
(0.4714)\end{array}$ & $\begin{array}{c}-0.48461 * * \\
(0.2315)\end{array}$ \\
\hline CAP x PERIOD3 & $\begin{array}{c}-0.61155 \text { *** } \\
(0.1845)\end{array}$ & $\begin{array}{c}-0.64632 * * * \\
(0.1935)\end{array}$ & $\begin{array}{c}-1.25641 * * * \\
(0.2983)\end{array}$ & $\begin{array}{r}-0.45183 \\
(0.4619)\end{array}$ \\
\hline CAP x ISL & $\begin{array}{l}0.81389 \\
(0.6856)\end{array}$ & $\begin{array}{l}0.75626 \\
(0.6860)\end{array}$ & $\begin{array}{l}0.36319 \\
(0.9266)\end{array}$ & $\begin{array}{l}0.19130 \\
(0.4674)\end{array}$ \\
\hline CAP $x$ ISL $x$ PERIOD2 & $\begin{array}{c}-2.07830 * * * \\
(0.6804)\end{array}$ & $\begin{array}{c}-2.02474 * * * \\
(0.7011)\end{array}$ & $\begin{array}{c}-2.06266^{*} \\
(1.0793)\end{array}$ & $\begin{array}{c}-1.14886^{* * *} \\
(0.4330)\end{array}$ \\
\hline CAP x ISL $x$ PERIOD3 & $\begin{array}{r}-1.14456 \\
(0.9447)\end{array}$ & $\begin{array}{r}-1.11038 \\
(0.9718)\end{array}$ & $\begin{array}{r}-1.46762 \\
(1.3620)\end{array}$ & $\begin{array}{r}-0.55153 \\
(0.6623)\end{array}$ \\
\hline \multicolumn{5}{|l|}{ Bank controls } \\
\hline Bank size & $\begin{array}{c}0.20401 * * * \\
(0.0363)\end{array}$ & $\begin{array}{c}0.20952 * * * \\
(0.0383)\end{array}$ & $\begin{array}{c}0.29293 \text { *** } \\
(0.0693)\end{array}$ & $\begin{array}{c}0.10146^{* * * *} \\
(0.0274)\end{array}$ \\
\hline Bank age & $\begin{array}{c}-0.17262 * * * \\
(0.0491)\end{array}$ & $\begin{array}{c}-0.18201 * * * \\
(0.0512)\end{array}$ & $\begin{array}{c}-0.19773^{* *} \\
(0.0948)\end{array}$ & $\begin{array}{c}-0.15202^{* * *} \\
(0.0361)\end{array}$ \\
\hline Branch size & $\begin{array}{c}-0.00225^{*} \\
(0.0013)\end{array}$ & $\begin{array}{c}-0.00225^{*} \\
(0.0013)\end{array}$ & $\begin{array}{c}-0.00302^{* *} \\
(0.0014)\end{array}$ & $\begin{array}{l}0.00305 \\
(0.0020)\end{array}$ \\
\hline Listed & $\begin{array}{r}-0.05325 \\
(0.0373)\end{array}$ & $\begin{array}{c}-0.05393 * \\
(0.0319)\end{array}$ & $\begin{array}{l}0.01587 \\
(0.0322)\end{array}$ & $\begin{array}{l}0.01376 \\
(0.0256)\end{array}$ \\
\hline State-owned banks & Yes & ----- & ----- & ----- \\
\hline Private-owned banks & Yes & Yes & ----- & Yes \\
\hline Foreign-owned banks & Yes & Yes & Yes & ----- \\
\hline Islamic banks & Yes & Yes & Yes & Yes \\
\hline Bank-fixed effects & Yes & Yes & Yes & Yes \\
\hline Time-fixed effects & Yes & Yes & Yes & Yes \\
\hline Observations & 2,361 & 2,170 & 1,125 & 1,292 \\
\hline R-squared & 0.1157 & 0.1188 & 0.1599 & 0.4270 \\
\hline
\end{tabular}

Statistical significance is indicated by $* * * p<0.01, * * p<0.05, * p<0.1$ 
interaction term CAP x ISL is non-significant). In the post-crisis period, in Period 2, conventional depositors kept disciplining their banks $\left(\alpha_{1}+\alpha_{2}\right.$, i.e., the sum of the coefficients of $C A P$ and $C A P \times P 2$, respectively, is positive for all different sample compositions). Results for Islamic depositors, however, indicate that the capital ratio had not an effect on the direction of deposit flows in a way that market discipline operates. In the post-deposit insurance reform period, in Period 3, the sensitivity of conventional deposits to bank capitalization is positive. More importantly, it seems that the unification of the deposit insurance schemes has restored market discipline of Islamic depositors (sum of the coefficients $\left(\alpha_{1}+\alpha_{4}\right)$ and $\left(\alpha_{3}+\alpha_{6}\right)$ is positive and statistically significant for all sample compositions), confirming our previous findings. In the full sample estimation (1998Q1-2012Q4), we, in fact, show that sensitivity of deposit flows to bank capitalization between Islamic and conventional depositors is only different in the period when Islamic banks had to operate under an Islamic deposit insurance scheme. This finding implies that the control group of conventional banks constitutes a valid counterfactual, which is in support for the difference-indifferences estimator used in this study.

\section{Discussion and concluding remarks}

Our results reveal that, with the introduction of an Islamic deposit insurance scheme, Islamic bank depositors did behave differently than their conventional counterparts and that these differences are substantial. More specifically, in the period when Islamic deposit insurance was introduced, and compared with their conventional peers, we consistently observe that the sensitivity of Islamic depositors to bank risk was annihilated. More specifically, we do not observe risk aversion of Islamic depositors as they do not exhibit behavior that is consistent with both quantity and price-based disciplining. At first glance, our results might seem puzzling why Islamic depositor reactions are different from their conventional peers, and subsequently switch decisions with the unification of the deposit insurance. However, this is less so if we take into account the very nature of the deposit insurance reform. This finding is likely due to the specific design of the Islamic deposit insurance scheme that was created immediately after the crisis. This scheme was administered by the 'Union of Private Finance Houses', consisting of only a handful of Islamic banks. The Union was empowered to act as the resolution authority for non-viable banks, and was charged to promote sound risk management practices over its members. The Islamic deposit insurance fund was interest free and Sharia compliant, and once the license of an Islamic bank was revoked, the liquidation had to be executed by the Union, and the insured deposits had to be settled by the Islamic insurance fund. Furthermore, the Union was mandated to detect early warning signals so that it could intervene timely in the resolution of troubled banks. By remaining silent, Islamic depositors may have delegated their monitoring responsibility to this Union. It can be argued that the replacement of market supervision by mutual supervision among member banks may be simply a consequence of rational behavior. Particularly, the stakes of Islamic banks were large in case of a failure since the scheme was backed by them, and the limited number of banks was conducive to robust oversight. 
Conversely, in the post-reform period, we observe that Islamic depositors have started to discipline their banks. In other words, if the bank fundamentals turn out to be weak, depositors indeed want to exercise power over bank management by withdrawing their funds. One explanation for this behavioral shift is that depositors may have started to hesitate about the Shariah-compliance of the deposit insurance under SDIF protection. This is a viable argument since the purpose of a separate Islamic deposit insurance scheme, which avoided the use of premiums paid by conventional banks, was to signal a radical break from the conventional banking system in order to soothe the sensitivities of the religiously inspired depositors. Hence, in Turkey, the Islamic deposit insurance allowed Islamic banks to give more security to their depositors, while keeping their operations ostensibly interest-free (El-Gamal and Inanoglu 2000).

The Islamic deposit insurance was instituted as a response to the failure of Ihlas Finans in 2001. By expanding the temporal scope of our analysis, i.e., including the time period before the 2001 financial crisis, we confirm our findings that depositors' sensitivity to the Islamic banks' capitalization was substantially muted with the introduction of an Islamic deposit insurance scheme.

We also can state that the risk aversion of depositors is contingent on the Shariahcompliance of Islamic banking. If depositors become suspicious about the operating environment of banks, they become more vigilant and pay greater attention to bank risk. This intuition suggests that the degree of risk aversion depends on the religious commitment of Islamic banks. In environments where the commitment is high, loyalty may win over risk aversion (and vice versa). Since the new deposit insurance lacks religious quality, Islamic depositors show a greater tendency to discipline their banks (risk aversion). From a regulatory point of view, perhaps unintentionally, the reform has increased market discipline among Islamic depositors, which has reinforced the first line of defense for a safe and sound banking system.

Acknowledgments We gratefully acknowledge the helpful comments and suggestions of Haluk Unal (Editor), an anonymous referee, Mehmet Asutay, Shaheed Ebrahim, Sabur Mollah, Phil Molyneux, Adam Ng, Steven Ongena, Vasileios Pappas, and Koen Schoors, as well as participants at the Islamic Banking \& Finance Conference, Lancaster, June 23-24 2014, Bangor-IRTI-JFSR Conference, September 15 2014, Financial Stability and Islamic Finance Conference, Ankara, November 3 2014, and the Research Seminar of Durham University, December 102015.

\section{References}

Abedifar P, Molyneux P, Tarazi A (2013) Risk in Islamic banking. Eur Finan Rev 17(6):2035-2096

Admati AR, Pfleiderer P (2009) The "wall street walk" and shareholder activism: exit as a form of voice. Rev Financ Stud 22(7):2645-2685

Akyüz Y, Boratav K (2003) The making of the Turkish financial crisis.World. Development 31(9):1549-1566

Askari H (2012) Islamic finance, risk-sharing, and international financial stability. Yale J Int Aff 7(1):1-8

Aysan AF, Dolgun MH, Turhan MI (2013) Assessment of the participation banks and their role in financial inclusion in Turkey. Emerg Mark Fin Trade 49(5):99-111

Aysan AF, Disli M, Ozturk H, Turhan IM (2015) Are Islamic banks subject to depositor discipline? Singap Econ Rev 60(01):1550007

Baele L, Farooq M, Ongena S (2014) Of religion and redemption: evidence from default on Islamic loans. J Bank Financ 44:141-159 
Banking Regulation and Supervision Agency BRSA (2010). From Crisis to Financial Stability (Turkey Experience). Working Paper (Revised third edition).

Barajas A, Steiner R (2000) Depositor behaviour and market discipline in Colombia. Working Paper WP/00/214, International Monetary Fund

Bashir A, Darrat AF, Suliman MO (1993) Equity capital, profit sharing contracts, and investment: theory and evidence. J Busi Fin Acc 20(5):639-651

Beck T, Demirgüç-Kunt A, Merrouche O (2013) Islamic vs. Conventional banking: business model, efficiency and stability. J Bank Financ 37(2):433-447

Berger AN, Turk-Ariss R (2014) Do depositors discipline banks and did government actions during the recent crisis reduce this discipline? an international perspective. J Financ Serv Res 48(2):103126

Berle AA, \& Means GGC (1932) The modern corporation and private property. Transaction Books

Brown JR Jr (2014) Secularism, Sharia, and the Turkish financial markets. Brooklyn J Int Law 40(2):407-463

Calomiris CW, Kahn CM (1991) The role of demandable debt in structuring optimal banking arrangements. Am Econ Rev 81(3):497-513

Caprio G \& Honohan P (2004) Can the unsophisticated market provide discipline? Policy Research Working Paper No. 3364. World Bank

Chapra MU (1992) Towards a just monetary system. The Islamic Foundation, Leicester

Čihák M, Hesse H (2010) Islamic banks and financial stability: an empirical analysis. J Financ Serv Res 38(2-3): 95-113

Cubillas E, Fonseca AR, González F (2012) Banking crises and market discipline: international evidence. J Bank Financ 36(8):2285-2298

Demirgüç-Kunt A, Detragiache E (2002) Does deposit insurance increase banking system stability? an empirical investigation. J Monet Econ 49(7):1373-1406

Demirgüç-Kunt A, Huizinga H (2004) Market discipline and deposit insurance. J Monet Econ 51(2):375-399

Disli M \& Schoors K (2013) Bank rebranding and depositor loyalty. Ghent University Working Paper No. 2013/867

Disli M, Schoors K, Meir J (2013) Political connections and depositor discipline. J Financ Stab 9(4):804-819

Ebrahim MS, Safadi A (1995) Behavioral norms in the Islamic doctrine of economics: a comment. J Econ Behav Organ 27(1):151-157

Edmans A (2009) Blockholder trading, market efficiency, and managerial myopia. J Financ 64(6):2481-2513

Edmans A, Manso G (2011) Governance through trading and intervention: a theory of multiple blockholders. Rev Financ Stud 24(7):2395-2428

El-Gamal M, Inanoglu H (2000) Islamic banking in turkey: boon or bane for the financial sector, In proceedings of the fifth harvard university forum on Islamic finance (pp. 7-20). Harvard University, Center for Middle Eastern Studies

El-Hawary D, Grais W \& Iqbal Z (2004) Regulating Islamic financial institutions: the nature of the regulated. World Bank Policy Research Working Paper No. 3227. World Bank

Errico L \& Farahbaksh M (1998) Islamic banking: issues in prudential regulations and supervision. IMF Working Paper No. WP/98/30. International Monetary Fund

Fama EF, Jensen MC (1983) Separation of ownership and control. J Law Econ 26(2):301-325

Flannery MJ (1998) Using market information in prudential bank supervision: a review of the US empirical evidence. J Money, Credit, Bank 30(3):273-305

Fueda I, Konishi M (2007) Depositors' response to deposit insurance reforms: evidence from Japan, 1990-2005. J Financ Serv Res 31(2-3):101-122

Hannan TH, Hanweck GA (1988) Bank insolvency risk and the market for large certificates of deposit. J Money, Credit, Bank 20(2):203-211

Hasan M, Dridi J (2011) The effects of the global crisis on Islamic and conventional banks: a comparative study. J Int Comm Econ Pol 2(2):163-200

Hasan I, Jackowicz K, Kowalewski O, Kozłowski Ł (2013) Market discipline during crisis: evidence from bank depositors in transition countries. J Bank Financ 37(12):5436-5451

Hilary G, Hui KW (2009) Does religion matter in corporate decision making in america? J Financ Econ 93(3): 455-473

Ioannidou V, \& De Dreu J (2006) The impact of explicit deposit insurance on market discipline. De Nederlandsche Bank

Iqbal Z (1997) Islamic financial systems. Financ Dev 34:42-45

Jensen MC, Meckling WH (1976) Theory of the firm: managerial behavior, agency costs and ownership structure. J Financ Econ 3(4):305-360 
Karas A, Pyle W, Schoors K (2013) Deposit insurance, banking crises, and market discipline: evidence from a natural experiment on deposit flows and rates. J Money, Credit, Bank 45(1):179-200

Khan MS, \& Mirakhor A (1989) Islamic banking: Experiences in the Islamic Republic of Iran and in Pakistan. IMF Working Paper No. WP/89/12. International Monetary Fund

Martinez Peria MS, Schmukler SL (2001) Do depositors punish banks for bad behavior? market discipline, deposit insurance, and banking crises. J Financ 56(3):1029-1051

Miller AS, Hoffmann JP (1995) Risk and religion: an explanation of gender differences in religiosity. J Sci Study Relig 34(1):63-75

Mills PS, Presley JR (1999) Islamic finance: theory and practice. Macmillan, London

Nier E, Baumann U (2006) Market discipline, disclosure and moral hazard in banking. J Financ Intermed 15(3): 332-361

Park S, Peristiani S (1998) Market discipline by thrift depositors. J Money, Credit, Bank 30(3):347-364

Prean N, Stix H (2011) The effect of raising deposit insurance coverage in times of financial crisis-evidence from Croatian microdata. Econ Syst 35(4):496-511

Safieddine A (2009) Islamic financial institutions and corporate governance: New insights for agency theory. Cor Gov An Int Rev 17(2):142-158

Sironi A (2003) Testing for market discipline in the european banking industry: evidence from subordinated debt issues. J Money, Credit, Bank 35(3):443-472

Solé J (2007) Introducing Islamic banks into conventional banking systems. IMF Working Paper No. WP/07/ 175. International Monetary Fund

Starr MA, Yilmaz R (2007) Bank runs in emerging-market economies: evidence from Turkey's special finance houses. South Econ J 73(4):1112-1132

The Economist (2001). Full of Interest. February 15 